\title{
Paideusis
}

\section{Post-modernism and Post-compulsory Education}

\section{John Halliday}

Volume 14, Number 1, 2001

URI: https://id.erudit.org/iderudit/1072823ar

DOI: https://doi.org/10.7202/1072823ar

See table of contents

Publisher(s)

Canadian Philosophy of Education Society

ISSN

0838-4517 (print)

1916-0348 (digital)

Explore this journal

Cite this article

Halliday, J. (2001). Post-modernism and Post-compulsory Education. Paideusis, 14(1), 31-47. https://doi.org/10.7202/1072823ar

\section{Article abstract}

This paper examines and elaborates upon the work of two writers, Usher and Edwards who have explored the significance of post-modernism for those involved in the post-compulsory sector of education. They argue that postmodernism signals an increasing interest in this sector of education and a major challenge to the idea of compulsory schooling. In this paper it is argued that postmodernism challenges the very distinction between compulsory and postcompulsory education. It problematises and disturbs a number of entrenched assumptions about education, teaching and learning in interesting ways. The paper concludes with an outline of what formal education might become as a result of such problematisation and disturbance.
This document is protected by copyright law. Use of the services of Erudit (including reproduction) is subject to its terms and conditions, which can be viewed online.

https://apropos.erudit.org/en/users/policy-on-use/ 


\section{Post-modernism and Post-compulsory Education}

\section{John Halliday, University of Strathclyde}

\section{Abstract}

This paper examines and elaborates upon the work of two writers, Usher and Edwards who have explored the significance of post-modernism for those involved in the post-compulsory sector of education. They argue that postmodernism signals an increasing interest in this sector of education and a major challenge to the idea of compulsory schooling. In this paper it is argued that postmodernism challenges the very distinction between compulsory and postcompulsory education. It problematises and disturbs a number of entrenched assumptions about education, teaching and learning in interesting ways. The paper concludes with an outline of what formal education might become as a result of such problematisation and disturbance.

\section{Introduction}

Few readers interested in educational studies will have failed to notice the considerable interest that there now is in the topic of post-modernism (Blake et al, 1998; Parker, 1997; Stronach and MacLure, 1997; Usher and Edwards, 1994). Nor will they have failed to notice that this topic can be a source of irritation for some critics who regard post-modernism as fashionable overblown hype. Claims such as those made by Baudrillard that the Gulf War did not happen and that the multiple disconnected images of 'hyper reality' replace the outmoded concept of reality seem to provide an easy target for these critics (Lyon, 1994; p. 52). They may point out that even if reason cannot be legitimated without circularity and the notion of an objective reality is problematic, it is not advisable to try to walk through walls, ignore the physiology of pain nor give up on the use of washing machines because there is something not quite right about electromagnetic theory! They may also point out that there are some facts of the matter and that not all interpretations are the slaves of social interests (Gellner, 1992). These critics might accept that the belief in critical reason, private freedom and progress through the application of natural science has been seriously eroded. They might also accept that modern forms of foundationalism and essentialism seem untenable. Yet for them, postmodernism is taken more as a symbol of challenge to the ideals of the late eighteenth century Enlightenment than as a radical break with those ideals. They would not want to claim that there is no reality, simply many different ways of 
describing that reality (Giddens, 1992; Bauman, 1992).

Robin Usher and Richard Edwards have been at the forefront of those who have examined the relationship between post-modernism and education. Writing together, individually and with other partners, they have explored some meanings of post-modernism and have argued that post-modernism is especially significant for those involved in post-compulsory education. Just as compulsory education and modernism cohere, so for Usher and Edwards (1994) the prefix 'post-' may be placed in front of both terms to disturb the coherence in an interesting way. 'Post -' here is taken to mean 'after' or 'following' in a temporal sense. If modernism includes a belief in disengaged reason based on certain privileged forms of objective knowledge then an education based on modernism should enable people to exercise that reason and acquire that knowledge. Compulsory schooling can be justified as the most efficient and equitable means of such enabling. If post-modernism celebrates the ideas of engaged reason, textuality and knowledge that is always connected with power, then an education that is sympathetic to post-modernism encourages difference and the deconstruction of texts to reveal unforeseen relationships between the self, knowledge, power and the world. It encourages people to acquire new ways of talking, thinking and writing as and when they need and to learn to reorient themselves when existing conditions get in the way of their interests.

Post-modernism challenges educational theorists to look beyond compulsory schooling and the supporting ideas of liberal education, personal autonomy and the development of mind. Indeed post-modernism signals a major challenge to the very ideas of a liberal education and autonomous subjects. But it also highlights and problematises many of the notions current in the postcompulsory sector too - empowerment, experiential learning, consumerism, managerialism and vocationalism. In that way post-modernism shifts theoretical interest towards post-compulsory education at the same time as it debunks a liberal education upon which the idea of compulsory schooling rests. Usher and Edwards share with other writers who are fascinated with post-modernism, a reluctance to draw practical implications from their work. They resist such 'closure' (Usher and Edwards, 1994, p. 207). In this paper however, it is argued that post-modernism does have practical implications for formal education and an attempt is made to set out some of these implications.

\section{From Modernism to Post-modernism}

The distinction between a knowing subject and an object to be known is 
fundamental to modernism. This distinction underpins the scientific quest for objective knowledge through inductive reasoning from particular observations to general theories. It also underpins the idea that children need to acquire this knowledge in order to become autonomous subjects who reason in a disengaged way about what they ought to do. It is as if their pre-engagement in existing practices and previous socialisation could be and should be thought through afresh in the light of this objective knowledge. Modernists hold that through collective emancipation from habit and tradition, disputes between people may be settled rationally. Through such emancipation, social cohesion might be assumed to be ensured through an ever expanding consensus based on objective knowledge provided by scientific methodology.

A number of factors serve to damage confidence in the modernist project however. First there is something of a crisis of values in western liberal democracies. The consensus that was expected to sustain liberalism is fragmenting (Jonathan 1997). The idea of progress through science is damaged as technological applications of science lead to difficulties such as environmental degradation. The benefits of technology are not now so obvious as they once were when electric motors were invented for example. Beliefs in scientism - the idea that all fields of enquiry should be based on natural science and technocracy - the idea that all forms of organisation should be regarded as forms of technology have been seriously eroded. This erosion is related to the realisation that the knowing subject is also an object to be known.

Post-empiricist philosophers of science demolish the knowing subject/ known object distinction and the idea that reality can be known through one theoryneutral observation language. Gadamer (1975) and Kuhn (1962) are among those who lead away from the apparent objectivism of a naive empiricism towards the reinstatement of the pre-Enlightenment uses of the term 'prejudice' and the importance of hermeneutics to the logic of scientific development. The ideas of a decentred self and pre-understandings that must remain implicit come to be accepted as it is recognised that all reasoning is bound to the context in which the reasoning takes place. There is no true, essential or natural self to be discovered. The self is constituted through engagement in social practices and the language used within those practices.

This lowering of the status of science from its Enlightenment pedestal as a set of master language-games is presumed by Lyotard to present a problem of legitimation for political decision-makers and educators. The modernist solution to this problem has been for governments to spend large amounts of money to enable 
science to "pass itself off as an epic", as Lyotard (1984, p. 27) puts it. In that way the state's own credibility and the public consent that the state's decision-makers need is based on that epic. The implication of this solution is that science needs other kinds of language games to function as an epic in order to legitimate itself. For example science may be legitimised on the grounds that it emancipates humanity from superstition and dogma. Compulsory schooling may then be legitimised as the means of transmitting scientific knowledge so that people may become autonomous as they learn to base their actions on objective knowledge of the world.

Lyotard (1984, p. 33) identifies a second 'grand narrative' which serves further to legitimise science. This second 'grand narrative' is based on the idea that science is a language game that links different forms of knowledge together. This Hegelian idea is perhaps best exemplified by the fascination within science for discovering the ultimate theory that explains everything in terms of fundamental particles, waves, fields or big bangs. Science may be seen to offer the possibility that knowledge forms a unity and that an initiation into a common cultural inheritance is possible and desirable as a means of promoting social cohesion. Yet, as Lyotard points out, somehow the contingency of events frustrates the unifying thrust within science. Scientific disciplines fragment rather than unite in the face of technological advances. These advances have led to such a proliferation of information that it no longer seems plausible to believe that students should be inducted into a fixed body of knowledge. A new meta-narrative emerges according to Lyotard as a response to this breakdown in the earlier meta-narratives. This new meta-narrative takes the form of the managerialist discourse of efficiency which can have no end other than to serve powerful interests. According to Lyotard "scientists, technicians and instruments are purchased not to find truth but to augment power" (Lyotard, 1984, p. 46)

\section{Post-Compulsory Education}

Once it is conceded that formal education cannot be legitimated by science then the notion of education as initiation into a common curriculum entitlement becomes marginalised. Instead people acquire whatever skills or information they need to keep up with the fragmentation of practices and maximise their 'performativity' (Lyotard, 1984, p xxiv). Whereas the notion of education as initiation (Peters 1966) may be seen to underpin compulsory education, it is performativity that comes increasingly to seem to underpin post-compulsory education. The most obvious powerful interest which performativity serves is capital accumulation. 
The fulfilment of this interest requires people to behave as ideal consumers, ever restless to discover new desires and to satisfy them in an increasingly short time frame. Paid work enables such behaviour as does the narrative that the nature of work now changes so rapidly that individual prosperity and national economic performance can only be secured if the rate and frequency with which people learn changes rapidly too (Winch 2000). But of course people cannot know what to learn in this presumed rapidly changing world of work - their fields of work are chosen for them by economic considerations beyond their control. While a post-compulsory education must relate to this uncertain world of work in order to attract students, ironically in the UK as elsewhere, it does so through offering vocational qualifications that in many cases take the form of the most specific list of learning outcomes. Yet achieving such a list can amount to no more than an ungrounded hope for which students must pay in order to keep up with a presumed rapidly changing jobs market. Hence a post-compulsory education is an integral part of the consumer oriented world for which it prepares its students.

Students involved in this type of education can legitimately be regarded as consumers, who cannot be entirely sure what they are purchasing. They are often offered guidance and counselling by agents of the provider to ascertain what purports to be their learning needs but what might more plausibly be regarded as the seller's commercial needs. They are offered a choice from a controlled range of learning programmes, units or modules that are delivered to them. Delivery here very often involves an illusion of progressivism as if students took charge of the delivery in some sense. Experiential learning of the sort that Dewey (1916) might have approved has been partly taken over by formal institutions of post-compulsory education as if experience has to be formally circumscribed before its learning potential can be realised. In these ways all learning after school becomes formalised and ritualised according to the norms of institutions that pride themselves on being customer focused, humane, efficiently managed, and dedicated to manufacture demand and then to satisfy it on an ongoing basis. An overriding instrumental ethos of vocationalism is present within this type of education along with the language of economic efficiency (Halliday, 1990, Hyland, 1994, 1997; Standish, 1997) (keywords highlighted in italics).

Within this description of post-compulsory education, it is not hard to detect ambivalence between choice (between modules) and formalisation (within modules as assessment criteria), between progressivism (choice of method) and the fixation of ends through systems of vocational qualifications, between consumerism (a sovereign right to determine the purchase) and the idea that only through formal

Paideusis 14:1, 2001 
counselling can learning needs be established. Usher and Edwards express this ambivalence in the following way with reference to the fashionable notion of experiential learning:

By foregrounding experience as a site for the cultivation of desire ... experiential learning has both an emancipatory and an oppressive potential. ... Selfdisciplined consumers are seduced rather than repressed into conformity by the lure of the commodification of their experience into qualifications that might bring them some reward. (Usher and Edwards, 1994, p. 205)

This ambivalence may not be so much a feature of post-modernism however as a result of tension between the modernist aspirations of governments and corporations to control and cultural post-modernism that is always tending to frustrate those aspirations (Hartley 1998). Governments are increasingly concerned about a lack of international competitiveness among their businesses and a need to legitimate the view that they are in a position to do something about this. They believe that a more flexible workforce is the key to improve matters (Edwards 1997). Post-modernism legitimates the increasingly short-term nature of employment opportunities by highlighting the supposedly rapid rate of technological and other sorts of change.

Institutions offering opportunities for post-compulsory education are therefore funded by governments to offer a continually changing portfolio of learning opportunities. In that way they try to keep up with customer preferences and business demands. At the same time the notion of core skills and competencies has entered the curricula of these institutions to suggest that there is, after all something coherent about the diverse range of learning opportunities on offer. These notions serve to legitimate the state's continuing involvement in the postcompulsory sector. Without them it might appear as if consumerism would serve to regulate the learning opportunities that are on offer from colleges, private trainers and elsewhere in the face of demand from business and individuals. The idea that there is after all a core to these diverse activities offers some comfort to the modernist idea that the common good is enhanced when more people are educated to take on the unknown challenges of the future.

Foucault $(1979,1980,1981)$ is a profound critic of the humanistic discourse of progress, emancipation and betterment that governs modern contemporary knowledge-power formations and which reinforces the effects of these formations. Foucault regards modern forms of governance as being secured partly through formal systems of education. In essence some subjects are taught to discipline themselves through such systems. For them schools and prisons share much in common. In contrast to the modernist ideal of disinterested knowledge as that which 
is only possible when power is not exercised, Foucault (1980) tries to show that knowledge and power are inseparable and that truth is necessarily produced rather than simply discovered. In that way discourses do not describe independently existing objects but constitute their very identity. What is to count as an object and who are to be the final arbiters of what is to count as an object are the important questions for Foucault. Foucault's analysis is not a straightforward appeal to the idea that certain discourses are more powerful than others. There is no master discourse to which appeal can be made to adjudicate between discourses. Rather power circulates around discourses and a form of sceptical enquiry that is termed genealogy may be used to trace this circulation.

For example Foucault (1981) argues that the practice of confession is so ingrained that it is always likely to be utilised in what he calls the will to knowledge. Usher and Edwards (1994, p. 95) develop this argument to show that guidance and counselling may be seen as discourses that harness the power of confession within post-compulsory education. This power is derived from the idea that confession is a discovering of truth about the self that is located in an innermost nature. Following Foucault however, such supposed truth is produced within the discourse of guidance and counselling and current methods for guiding and counselling students actually serve as a way of disciplining and controlling them. The language of 'meeting individual needs' which pervades the post-compulsory sector would be another example where an appeal is made to the idea that people may come to know both what their real needs are and when those needs have been satisfied. In that way it seems good to involve learners in their own learning as it might be supposed that they themselves are best able to decide what they need to learn. Yet the discourse of self-directed learning is commodified into an offer to students of a choice from a very limited range of carefully controlled options or 'modules', as these options are often termed.

In this way the liberal humanistic discourse of counselling can be just as deficient as the discourse of managerialism. Both are constituted within modernism through the idea of a subject coming to know an objective reality. Whether the discourse is focused on the subject (liberal humanism) or the objective reality of measurement (markets, managers and economic success) the effect is to reinforce the educational structures that are founded on the ideals of the Enlightenment. For example on the one hand the discourse of competence is very much related to the objectification of an element of learning to be measured or marketed. On the other hand however the discourse also trades on the liberal-humanistic side of the dichotomy too as if by acquiring competencies people become 'empowered'. 
Guidance and counselling personnel may be found helping learners to devise their own programmes of study and to select those competencies that they wish to achieve. At the same time learners are to be given accreditation for their prior learning as recognition of their sense of self-worth. No longer are students to be led to failure through those supposedly unpleasant, end-of-term, norm-referenced competitive examinations. Now students are continually given opportunities to be assessed as competent or given help if they are in difficulty. New submission times for assessment are negotiated with counsellors who are supposed always to be sympathetic to the personal difficulties of students. This sympathy and concern may amount to a very powerful technology of continually expanded surveillance. Students do not learn so much about new possibilities for themselves as about how to judge themselves against supposedly objective criteria - they become their national vocational qualifications, as Usher and Edwards (1994, p. 110) put it with reference to the set of qualifications now dominant in the post-compulsory sector in the UK.

This discussion of the ambivalence of post-modernism serves as an important warning to those educators who uncritically adopt the language of empowerment, experiential learning, interdisciplinarity and student-centredness. The accreditation of prior learning, self-appraisal, records of achievement and vocational competence all may be seen to trade on the language of progressivism and liberalism to reinforce dominant and oppressive forms of self-surveillance and educational consumerism. Post-modernism is ambivalent in a more fundamental sense however concerning the possibility of a socially just and critical compulsory education. There remains an imbalance between those who by and large succeed at the primary opportunity to achieve at school and those who do not. There is also an imbalance between those who by and large enjoy secure employment and those who do not. There is finally an imbalance between those who have the confidence to go on and learn things on their own such as how to use the latest version of an operating system for their computers and those who do not have such confidence. They may lack confidence partly because of failure in prior learning experiences at school but also because they cannot afford, nor see an immediate need to afford the hardware upon which to practise. There is now an obvious blurring of boundaries between learning, work and leisure which those with confidence, resources and certain basic abilities can exploit to their advantage once they leave school. Those for whom schooling is a negative experience however remain cut off from opportunities that arise as a result of such blurring. For them schooling is the opposite of an educational experience. 
This imbalance serves the interest of capital accumulation but not the interest of social cohesion. Whereas capital can now flow round the globe almost instantaneously and companies are now freer to move to cheaper sources of labour than ever they were, most people are not. Whereas companies can be run by an elite of managers and shareholders able to function in any location through the technology of communications, those who are managed tend to be tied to one location. The latter have neither the resources nor the inclination to move. As Bauman (1998) points out, such technology tends to detach a managing elite from the majority of the work force. It cuts the elite off from what previously would have been their obligations and duties towards those they control. As he puts it

Capital can always move away to more peaceful sites if the engagement with 'otherness' requires a costly application of force or tiresome negotiations. No need to engage, if avoidance will do. (Bauman 1998, p. 11)

For theorists such as Bauman (1998), Harvey (2000), Castells and others (1999), the closing off of public spaces, the fencing in of managerial locations, the formation of global networks, are necessarily destructive of democratic community. There seem few reasons why a compulsory education should initiate people into a common cultural inheritance in the interests of social cohesion if the interest of capital accumulation is dominant. Rather a compulsory education serves the interest of capital accumulation primarily by acting as a device for selection between the elite and the managed. Such an education always did involve the acquisition of positional goods but these goods come to dominate as the possibilities of community and common culture become marginalised. Those with the resources to do so pay heavily to try to secure such positional goods. Hence the vocationalism dominant within the post-compulsory sector spreads to the compulsory sector too. But in this latter sector the prime function becomes vocational selection rather than vocational preparation.

According to this argument, all that appears to be left for the state to do is to provide a simple security and selection service for companies and corporations. A compulsory education does both. It selects an elite and encourages discipline and conformity in the rest by failing to develop collective imaginations, cognitive abilities or confidence ever to look beyond a current predicament. Such an education is complemented by a social security and prison service which mops up what turns out across the developed world to be an ever increasing number of people who fail to develop sufficiently their capacity to consume in the normal ways (Harvey 2000). Hence post-modernism disturbs entrenched assumptions about the humane pretensions of both compulsory and post-compulsory education. 


\section{Beyond Dichotomies}

Lacan (1979) writes of four fundamental discourses of relevance to education: the discourse of the university, the discourse of the master, the discourse of the hysteric and the discourse of the analyst. Of these the discourse of the analyst is taken by Usher and Edwards (1994, p 78) to be of most educational interest for teachers in the post-compulsory sector. Whereas the discourse of the university is taken to be of most interest for teachers in the compulsory sector. In this sector it is plausible to see the role of the teacher as a transmitter of knowledge to her pupils who make steady progress away from ignorance. As Usher and Edwards (1994, p. 77) put it

The idea... that humanity progresses through the move from ignorance to knowledge, is a characteristic of the modern, and indeed it is possible to see Lacan's discourse of the university as referring precisely to the place of knowledge in the project of modernity.

In contrast students in post-compulsory education might be assumed already to have acquired a good deal of knowledge without appreciating its significance. Within the discourse of the analyst, the analysand is brought to the point where she recognises, acknowledges and starts dealing with 'master signifiers' (Bracher, 1993, $p$ 24). What the analysand has taken as unproblematic and unquestioned is relativised on the basis that it was acquired through a particular socialisation. The analysand comes to recognise the alienation that is brought about by repressed desire. By analogy Usher and Edwards argue that learning for post-modernists is not so much conceived within the discourse of the university as the acquisition of knowledge. Rather learning is conceived within the discourse of the analyst as the bringing about of a different learning disposition. An apparent need to acquire knowledge comes to be seen as a block on more fruitful analysis of a predicament in which the self and the world are bound in unpredictable ways.

It is easy to see why a Lacanian account of teaching and learning might be most attractive to those working in adult education where students like their teachers may be supposed, through previous schooling and socialisation, to have acquired some 'master signifiers' which need to be discarded or relativised. It is not clear that what Lacan calls the discourse of the university should be given up entirely however. Knowledge may yet be important to adult learners even though its importance is not likely to be realised by teachers who conceptualise it as something that is transmitted. Learning cannot consist entirely of the discarding of master signifiers, even in the case of adults learning. Some notion of public knowledge has a part to play in helping both analyst and analysand to discard master signifiers in the most educationally advantageous way. The whole question of whether 
knowledge is public or private is important here and it would be a mistake to conceive the question in subjective terms only. It would also be a mistake to characterise compulsory education as necessarily consisting of an uncritical acceptance of a cultural inheritance of accumulated knowledge. The idea persists that through collective emancipation from habit and tradition, disputes between people may be settled rationally. Post-modernism has removed the idea that metanarratives can 'trump' such disputes to bring about a clear resolution on one side or the other. That does not mean that notions such as truth, objectivity and rationality are useless or that social cohesion is an impossibility. Rather the ideas of uncertainty, provisionality and fallibility simply have to be built more fully into political and educational structures.

Hence it is a mistake to characterise compulsory/post-compulsory and modernism/post-modernism as dichotomous and this mistake becomes even clearer when writers who claim that they are 'fascinated' by the notion of post-modernism wish to tell others of their fascination. These writers face the central difficulty of their own and their reader's very embeddedness in the language and conventions of modernity. One of these conventions is to try to elucidate the general features that are presumed to bring coherence to the use of the terms that feature in any exposition of ideas. Another convention is to try to draw implications from this elucidation. With a term such as post-modernism these conventions may be unhelpful. That is because of the way that the term functions as a sort of celebration of the impossibility of finding uniformity between and within practices or forms of discourse. The search for a meta-narrative to bring coherence to a range of interpretations is itself predicated on a mistaken modernist notion that theorising may be conceived only as a search of this kind. So an attempt to explicate a term such as post-modernism may be seen to be just the sort of meta-narrative that some post-modernists want to resist. Of course it is not clear just how such resistance could be formed without drawing on the idea that some narratives are more generalisable or acceptable than others. Moreover it is not unreasonable to look for another meta-narrative to replace the damaged meta-narratives of the Enlightenment and to give guidance as to how to proceed. How do theorists of a post-modernist persuasion get out of this bind?

One approach which has many attractions would be to avoid the use of the term altogether and to refer to particular writers who say particular things at particular times. If others care to label some of these writers as post-modernists and their work as contributing to post-modernism then so much the worse for them. So much the worse for the rest of us as we try to disentangle the inevitable paradoxes 
that result when we write in this way. Unfortunately this approach is not now possible because the use of the term is so entrenched. Another approach would be to write in such an oblique fashion that through what Usher and Edwards call "creative drifting" the text resonates with the readers' concerns. Nothing quite like truth emerges as "the touch of truth", as Usher and Edwards (1994, p 124) put it. It is not entirely clear what Usher and Edwards mean by these phrases. Perhaps they mean that by writing suggestive and perhaps ironical texts, the pretensions of grand ideas will be debunked. That is not to say that this writing will be reductive. The opposite may be the case and greater richness may be shown through the complication. On the other hand the writing could be unsettling, destabilising or unproductive. As Lyotard (1984) suggests, philosophy ought to adopt the processes of art.

A third alternative favoured in this paper would be to reject the idea that modernism and post-modernism are in a dichotomous relation (Leicester 2000). Once it is conceded that language cannot correspond to reality and that theories may only be compared against each other and not against a theory-neutral observation language, then theory preference becomes a form of practical hermeneutics. According to such a form a necessary commitment to a public language provides ways of determining good from bad moves within language games and between language games. Wittgenstein's (1953) disdain for general theory and concentration of philosophical focus on particular cases, Heidegger's (1962) decentring of the subject and explanation of Dasein, Rorty's (1980) demolition of the account of philosophy as a mirror of nature, Quine's (1960) notion of a seamless web and argument against there being a "cosmic vantage point" - all may point us towards post-modernism. The difficulty is that an overblown use of that term may lead us into a number of false dualisms such as objective/subjective and liberal/vocational rather than enabling the solution of educational problems in a piecemeal manner. Whatever guides these pragmatic endeavours may not be set out clearly if at all. That is not however to deny their importance nor especially to celebrate a difficulty in generalising from them.

For example as Winch (2000) points out, it is perfectly understandable that people might be prepared to pay to gain a qualification in order to secure a job. That does not mean that this aim necessarily precludes all other educational possibilities. As he puts it, a vocational preparation

also gives one the means to pursue other aspects of the good in one's life ...it entails features that are common to liberal forms of education ... it includes a strong and continuing element of moral education and, particularly in some occupations a strong element of aesthetic education. (Winch 2000, p. 121)

To take a further example, it is widely claimed that the University is in 
crisis as a result of post-modernism's assault on the privileging of academic knowledge and lengthy courses leading to qualifications in academic practices (Barnett and Griffin 1997). Yet as Haldane puts it in the same volume (p 53), "my enduring impression is that those who speak longest and loudest about crises of knowledge are those least possessed of it." It may well be convenient to some egalitarians and some intellectuals to deny that there are hierarchies of learning and institutions but for Haldane, divisive though it may be, they are wrong. He goes on, "No one who cares about intellectual discipline and who has undergone a rigorous training in a difficult field can doubt that deep knowledge is hard won." (ibid.) Moreover no one who has actually engaged in deconstruction could doubt that such deep knowledge is precisely what makes convincing deconstruction possible. There is no need of a meta-narrative to doubt that there are some moves within practices that are more difficult to make than others - that these moves sometimes require more cognitive ability than others - and that some forms of knowledge are more enduring than others. Rather than suggesting that the distinction between modernism and post-modernism coheres with the distinction between knowledge and deconstruction and the distinction between compulsory and post-compulsory, post-modernism might be viewed as a significant challenge to dichotomous thinking in general.

While performativity may well serve the interests of capital accumulation, it may serve other interests too, such as the interests of those such as Haldane who seek to preserve practical hierarchies of all kinds without foundationalism. For him

reflection can provide reasons for choosing some routes and not others. Knowledge is possible: any sense of a general crisis of scepticism is therefore misplaced. Perhaps certain subjects are in trouble, but ... some areas lie nearer the intellectual surface and it may be that exposure has dried them up. If that should be so then those who wish to have rewarding careers as scholars should go deeper in the pursuit of truth (Haldane 1997, p. 65).

Education, the pursuit of truth, social justice and knowledge do not necessarily depend upon there being many institutions of compulsory education however. In this concluding section, it is argued that less compulsory education may be the most appropriate response to postmodernism.

\section{Towards Less Compulsory Education}

Wain (2000) agrees that the language and practice of post-compulsory education has become increasingly dominated by a master discourse of performativity. He considers whether there might be a possibility of sustaining a counter discourse based around the notion of justice. He notes however that this 
alternative seems to fall foul of the post-modernist's incredulity towards metanarratives of any sort whether based on justice or managerialism. Rather he favours a kind of 'guerrilla warfare' noting that

western democratic capitalist societies possess all the resources they require for their own self preservation, even if, as Habermas pointed out, their legitimacy is prone to recurring crises of different kinds. (Wain 2000, p. 49)

To be sure some institutions are based on a stronger sense of justice and faimess than others. Some statements are more generalisable than others. Knowledge statements tend to be of this form. But the truth of knowledge statements is contextually sensitive. This is not a form of relativism. There are indeed certain limiting concepts which will be important to any human society and in any life (birth, death, sexual relations). Conceptual schemes and contexts are not isolated from one another because they are unified within a person's life and the life of a group. There are some schemes that are more enduring. There are others that rightly disturb and edify those schemes. Within both compulsory and postcompulsory education, knowledge and analysis are important. Induction into a cultural inheritance can take place at any age in a piecemeal manner. Students may usefully be regarded as customers of a sort bound contractually to institutions of formal education. They learn things in all kinds of ways however and in all kinds of location. There are good reasons formally to offer all students a choice from a range of learning programmes. There is no reason to try to formalise experiential learning or guidance. There are however the strongest reasons to ensure that those learning programmes are rigorous and critical for otherwise there can be no point in following them.

What emerges from considering the symmetry between moderncompulsory, post-modern-post-compulsory is a fundamental challenge to the very distinctions themselves. This challenge supports a Deweyan sense of lifelong learning (Wain 1993) within which schooling is seen as a stage. It becomes hard to justify a compulsory education on grounds other than the publicly accepted need for everyone to acquire certain basic abilities such as counting, reading and writing and the widespread belief that such acquisition should take place early in a person's life. Certainly there are educational and political requirements that everyone should have an opportunity to learn whatever they have an interest in and that is thought to be worthwhile throughout their lives. In that way their learning is likely to be much more successful than when they are forced to attend school with others who have no interest in whatever is prescribed. Their confidence is not likely to be enhanced by such forced participation in activities at which they are likely to fail. They are not thereby encouraged to take up learning opportunities that are on offer within the 
rapidly changing cultural boundaries between work and leisure.

The modernist aspirations of the current compulsory school curriculum cannot withstand a challenge from post-modernism but nor can the techniques of the post-compulsory sector withstand that challenge either. If the arguments advanced in this paper are correct, the key question for policy makers becomes what resources should be provided for which learning opportunities that are not likely to be available unless supported by governments. It has already been indicated that a basic primary education would have priority. Thereafter whatever opportunities are supported by government should be legitimated on the grounds that they are not easily available elsewhere but are thought generally to be worthwhile and 'not likely to dry up' to use Haldane's (1997, p 65) metaphor.

Given that education is always in part a positional good, it might be felt that formal education must be a prime instrument to ensure an equitable opportunity to secure a share of that good. It is possible to follow post-modernism however and argue that the notion of positionality will become much more problematic than in the past and that ever stronger attempts to control and formalise education will be counter productive. That is not to suggest that notions of justice and equity are no longer important. Rather it is to suggest that the best ways of saving these notions from robbery of their moral force is to try to secure them on a local and particularised basis even though their Kantian force suggests generalisability. That such attempts may seem like guerrilla warfare against authoritative forms of governance based on modernism is to be expected. The warfare is likely to take place increasingly outside of institutions of compulsory or post-compulsory education because within such institutions, enemies are easily camouflaged as has been shown. Ironically, with less pretentious ideas of what formal education can do, more social progress might be made.

\section{References}

Barnett, R., Griffin, A. (1997) eds., The End of Knowledge in Higher Education, London: Cassell.

Bauman, Z. (1992) Intimations of Post-modernity, London: Routledge.

Bauman, Z. (1998) Globalisation: the Human Consequences, Cambridge: Polity Press.

Blake, N., Smeyers, P., Smith, R., Standish, P. (1998) Thinking Again: education after postmodernism, Westport: Bergin and Garvey.

Bracher, M. (1993) Lacan, Discourse and Social Change, Ithaca: Cornell University Press.

Castells, M., Flecha, R., Freire, P., Giroux, H. A., Macedo, D., Willis, P. (1999) Critical Education in the New Information Age, Lanham, Maryland: Rowman and Littlefield.

Coffield, F. (1999) Speaking Truth to Power, Bristol: The Policy Press.

Dewey, J. (1916) Democracy and Education, New York: The Free Press. 
Edwards, R. (1997) Changing Places? Flexibility, lifelong learning and a learning society, London: Routledge.

Foucault, M. (1979) Discipline and Punish: the birth of the prison, (trans. Sheridan, A.) Harmondsworth: Penguin.

Foucault, M. (1980) Power/Knowledge: selected interviews and other writings 1972-77, (ed. Gordon, C.) Brighton: Harvester.

Foucault, M. (1981) The History of Sexuality - an introduction, (trans. Hurley, R.) Harmondsworth: Penguin.

Gadamer, H. G. (1975) Truth and Method, (trans. Weinsheimer, J., Marshall, D.G.) London: Sheed and Ward.

Giddens, A. (1992) The Consequences of Modernity, Cambridge: Polity Press.

Habermas, J. (1992) The Philosophical Discourse of Modernity, (trans. Lawrence, F.) Cambridge: Polity Press.

Haldane, J. (1997) pp. 53-67 in Barnett, R., Griffin, A., op cit.

Halliday, J. S. (1990) Markets, Managers and Theory in Education, Basingstoke: Falmer.

Hartley, D. (1998) Reschooling Society, London, Falmer.

Harvey, D. (2000) Spaces of Hope, Edinburgh: Edinburgh University Press.

Heidegger, M. (1962) Being and Time, (trans. Stambaugh, J.) Oxford: Blackwell.

Hyland, T. (1994) Competence, Education and NVQs, London: Cassell.

Jonathan, R. (1997) Illusory Freedoms: Liberalism, Education and the Market, Oxford: Blackwell.

Kennedy, H. (1997) Learning Works: widening participation in further education, Coventry: Further Education Funding Council.

Lacan, J. (1979) The Four Fundamental Concepts of Psychoanalysis, (trans. Sheridan, A.) London: Penguin.

Leicester, M. (2000) Post-post-modernism and continuing education, International Journal of Lifelong Education, 19:1, pp 73-81.

Lyon, D. (1994) Post-modernity, Buckingham: Open University Press.

Lyotard, J. F. (1984) The Post-modern Condition: a report on knowledge, (trans.

Bennington, G., Massumi, B.,) Manchester: Manchester University Press.

Parker, S. (1997) Reflective Teaching in the Post-modern World: a manifesto for education in post-modernity, Buckingham: Open University Press.

Peters, R. S. (1966) Ethics and Education, London: Allen and Unwin.

Quine, W. V. O. (1960) Word and Object, Cambridge: MIT Press.

Rogers, C. (1983) Freedom to Learn, Columbus: Merrill.

Standish, P. (1997) Heidegger and the Technology of Further Education, Journal of Philosophy of Education, 31: 3, pp 439- 460.

Stronach, I., Maclure, M. (1997) Educational Research Undone: the post-modern embrace, Buckingham, Open University Press.

Usher, R., Edwards, R. (1994) Post-modernism and Education, London: Routledge.

Wain, K., (1993), Lifelong Education and adult education - the state of the theory, 
International Journal of Lifelong Education, 12:2, pp 85-89.

Wain, K. (2000) The Learning Society: post-modern politics, International Journal of Lifelong Education, 19:1, p. 36-59.

Winch, C. (2000) Education, Work and Social Capital, London: Routledge.

Wittgenstein, L. (1953) Philosophical Investigations,(trans. Anscombe, G.E.M.) Oxford: Blackwell.

\section{Author}

John Halliday is Professor in the Department of Educational Studies, University of Strathclyde, Glasgow, Scotland. His publications are wide-ranging but he has particular research interests in the philosophy of post-compulsory education.

E-mail: <j.s.halliday@strath.ac.uk>. 